\title{
The Studies of Architectural Design Method
}

\author{
Djoko Indrosaptono, Tri Susetyo Andadari, Alfanadi Agung Setiyawan \\ Department of Architecture, Faculty of Engineering, Universitas Diponegoro, Semarang, Indonesia
}

Corresponding e-mail: djokoindrosaptono@gmail.com

Article info:

Received: 29-03-2021, Revised: 18-04-2021, Accepted: 24-04-2021

\begin{abstract}
The design processes and strategies applied to each architect in carrying out their design tasks are different. The stages in producing architectural work can be based on the theory of certain design methods, intuition or design experience from each architect. As an architect, it is mandatory to know the design process in accordance with existing methods. There are several variables in the design method according to Jones and Schmitt. This study aims to find the variables most widely used by 8 architects in designing, including the average of the variables it uses. The method used in this research is quantitative method with one way ANOVA (SPSS V.22) as its statistical analysis, by examining the mean difference between the research objects. The literature study was used to obtain an analysis of the design process and the methods used by 4 well-known architects as their secondary empirical data source, while field observations in the form of direct interviews were carried out to obtain the reality of the design process for 4 local architects with various backgrounds and characteristics as well as different architectural works. Provisional estimates shows that the average level of architects using the same research variables and the design process variables that are most often used by architects in carrying out architectural designs, are the clarity of the need for the design function, the use of the drawing system and meaningful design results for the owner and logical to build.
\end{abstract}

Keywords: Design Process, Architecture, Design Methods

\section{Introduction}

The architectural design process is part of a complete building process, which consists of design, construction, management and use. An architect must know the correct design process so that the output obtained can be in accordance with the client's wishes, while still considering the effectiveness and financial side available. There is no standard order that requires how the design process is made, each architect has its own rules. However, several experts, including $\mathrm{J}$ Christopher Jones and Schmitt, GN, have formulated design methods in several classifications.

The approach to the three strategies of the design process, namely: modeling, sketching and a mixed strategy of the two. The design process in the early stage case studies has shown results that are close to the expectations of the client (Afify, Alhefnawi, Istanbouli, Alsayed, \& Elmoghazy, 2021).

Understanding 'ideology' or the principles that are believed to be the basis for making architectural designs, besides that, it is necessary to use the 'methods' used in implementing architectural designs as well as mutually supporting the success of a design. Therefore, it is very necessary to understand the design ideology that is always attached to the students (Billings \& Akkach, 1992).

A successful approach in designing architectural designs by applying architectural design knowledge in sequence which is presented in the architectural design literature and software as the main support (Geest, Tekinerdogan, \& Catal, 2021). 
The study of architectural design learning through practice-based research projects, by applying video games as an understanding of an architectural space can develop design methods as well as analyze its environment (Pearson, 2020).

The conceptual approach to architectural design is a complex process that draws on past experiences and high creativity to produce new designs. Most of the early approaches to the architectural design process were oriented towards the discovery of one's innovative and creative forms (Pena, Carballal, Fernandez, Santos, \& Romero, 2021).

The results showed that online teaching during the pandemic was in a regular meeting format with an emphasis on the design process, especially design theory, students were satisfied, but on the other hand, in terms of practice regarding the application of design, there are still many technical difficulties, therefore it still takes a longer or longer time duration (Ibrahim, Attia, Bataineh, \& Ali, 2020).

The results of the research analysis show that the use of living things that occur in a spatial design is not entirely theoretical or approximate, considering that this condition will soon become obsolete or left behind (Heil \& Vitalis, 2020).

The latest design work suggests the use of Evolutionary Algorithms (EA) thanks to its ability to obtain locally optimal architectural work. On the other hand, the fact that EA has shown interesting performance, the researchers in this case have considered the design task as a problem in optimization when gaps occur. A method approach that outperforms the latest and leading architectural works with three approaches namely: manual design, reinforcement-based generation in learning, and evolutionary optimization $(H$. Louati, Bechikh, Louati, Hung, \& Said, 2021).

The architects rated the effectiveness of the design review using Mixed Reality (MR) and the results showed it effectively communicated $85 \%$ of information to clients. Besides, it has the potential to increase the client's understanding of the aesthetic characteristics of the material (Carrasco \& Chen, 2021).

The transformation of architectural design practice for forty years has experienced a very high development due to the democratization of computer technology. Besides that, the typology of the design process model developed by Blessing (1995) is a design process model that reflects a parametric modeling tool that can reshape the design process practiced in an office engaged in architecture (Stals, Jancart, \& Elsen, 2021).

Research that proposes a smart design method that has stages of exploration of architectural design space with methods of minimizing various obstacles to client satisfaction, in this case the safety assessment process that leads to safety solutions for its users (Jiao et al., 2019).

Research studies the relationship between design and architectural research which includes the question of whether it can be viewed as a separate scientific discipline. Research assessment, provides a motive for identifying architecture as a scientific discipline, on the other hand the unique 'architectural' elements continue to be a problem that needs to be researched. Recent changes in understanding design that can accommodate various changes that occur in society require the involvement of researchers / practitioners in practice-based research in design (Luck, 2019).

Research results that provide strong and accurate design references to architects when performing design tasks. The design process is divided into three steps. The first step is to build a database by randomly creating research objects and performing simulations, the second step is to create a model by creating a building design simulation that requires enough time to quickly predict building performance, the third step is to optimize various objectives based on actual design constraints (Zou, Zhan, \& Xiang, 2021). 
For this reason, this study seeks to obtain the average value of the sample architect person, the average value of the variables from the Jones and Schmitt design method, as well as the highest ranking order of variables used by the sample person and the highest sample person order in applying the design method variables according to Jones. and Schmitt, presented in tabulated results from the SPSS software. (statistical package for the social science)

The method used in this research is quantitative, with one way ANOVA (analysis of variant) as a statistical analysis, by examining the mean difference between research objects. In this case 8 architects. The data search process was based on direct interviews with 4 architects who did architectural design and literature studies of 4 architects who were already wellknown and had works. Then scoring each architect as a sample person according to the variables that have been taken from the design theory of Jones and Schmitt.

The scoring results are processed in SPSS (statistical package for the social science) software to obtain the mean and ranking order, both the variable ranking and the person sample ranking.

\section{Design Definition}

There are many figures who try to define design and design methods. According to Jones (1972), in his book Developments in Design Methodology, quoted by Mohamad Ratodi (2017), it is stated that design has the meaning of initiating changes in man-made objects (Jones, 1972). Still in the same book he states that "Design process is choosing the best solutions out of several divisions of design solutions".

According to Asimow (1982), which defines design as a process of making decisions from apparent uncertainty, with firm actions for errors that occur (Asimow, 1962).

Meanwhile, Heath (1984) states that architectural design methods, which are often referred to as the model of activity, are actions that must be taken to obtain a solution to a design problem. Until it is finally built; this action is a problem solving process or design process (Heath, 1984).

\section{Design Methods}

In general, the design method proposed by Schmitt (1991) is divided into 3 categories, namely the Top-Down method, the Bottom-Up method and the Case-Based method, as seen in Figure 1.1.

The Top-Down method, is a routine design pattern, with the characteristics that the design problem is clear and the client's needs are well understood, that a prototype is available as a parameter for design and basic data for parameter variations and that the final design is produced by refining, not fundamentally changing the prototype.

The bottom-up method, is an innovative design pattern with characteristics as prototyping adaptations and combinations used if the refinement of the prototype is unsatisfactory, a combination of two or more prototypes is required, each of which has some of the desired properties.

The Case-Based method is a creative design pattern with the characteristics of developing a new solution partially from the previous one, the functional requirements \& object properties are not fully known and the final design can affect the definition of the original problem or even declare the problem irrelevant (Schmitt \& Chen, 1991). 


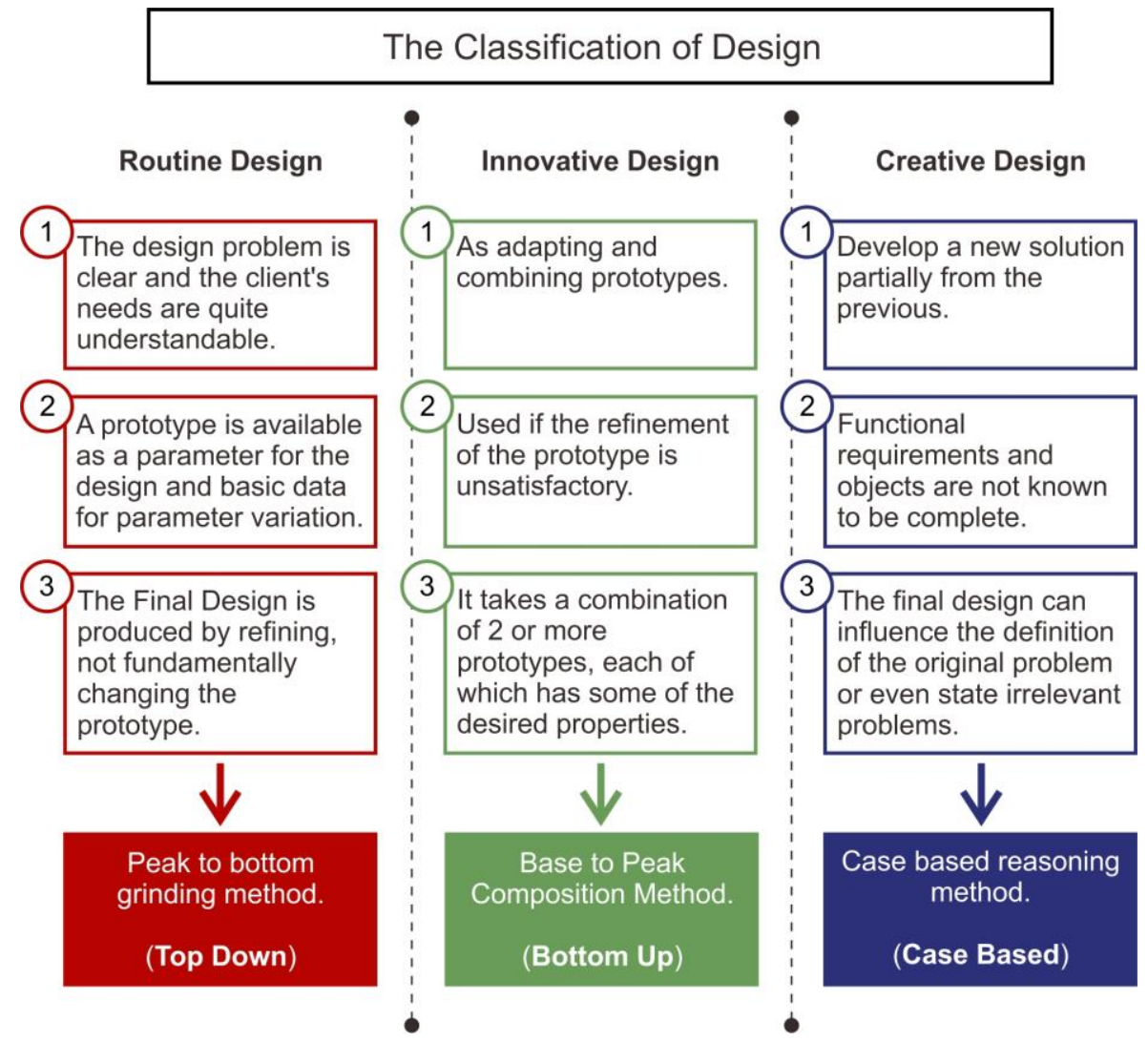

Figure 1.1. Design Classification According to Schmitt (Aditjipto, 1999)

In his book Design Methods, Seed of Human Futures, Christopher Jones stated that design methods are divided into 2 categories, namely traditional methods and modern methods, as shown in the Table 1.2 below.

Table 1.2. Christopher Jones's Design Classification (Jones, 1972)

\begin{tabular}{|c|c|c|c|c|}
\hline \multirow{2}{*}{$\begin{array}{l}\text { General } \\
\text { Design } \\
\text { Method }\end{array}$} & \multicolumn{4}{|c|}{ The Development of Design Methods by Jones (1972) } \\
\hline & \multicolumn{2}{|c|}{ Traditional Method } & \multicolumn{2}{|c|}{ Modern Method } \\
\hline \multirow{2}{*}{$\begin{array}{l}\text { Action } \\
\text { Method }\end{array}$} & \multirow{2}{*}{$\begin{array}{l}\text { Craft } \\
\text { Method }\end{array}$} & Trial and Error & \multirow{2}{*}{$\begin{array}{c}\text { Black Box Method } \\
\text { (Designed as } \\
\text { Black Box) }\end{array}$} & \multirow{2}{*}{ Inspiration, Ideas } \\
\hline & & Craft Evolution & & \\
\hline \multirow{3}{*}{$\begin{array}{c}\text { Action and } \\
\text { Rational } \\
\text { Method }\end{array}$} & \multirow{3}{*}{$\begin{array}{l}\text { Drawing } \\
\text { Method }\end{array}$} & Sketch Image & \multirow{3}{*}{$\begin{array}{c}\text { Glass Box } \\
\text { Method } \\
\text { (Designed as a } \\
\text { Glass Box) }\end{array}$} & Brainstorming \\
\hline & & Concept Image & & Syntetyc \\
\hline & & Detail Image & & Design Concept \\
\hline
\end{tabular}

The blackbox design method is carried out spontaneously by the designer. Ideas can come from anywhere and at any time to create a work. The characteristics are:

- The concept of creativity in design is not clear, it can be from dreams, inspiration, even from wangsit, or other trials. 
- It is difficult to explain the concept obtained, considering that the idea came spontaneously or dominantly because of previous experiences

- The creative process of a design cannot be seen clearly.

- The result of a work cannot be criticized.

- Production capacity that depends on the availability of time, mood and the designer's imagination.

This glassbox design method is carried out rationally and logically. The design concept that is made does not come spontaneously but goes through several stages which are carried out by considering certain things. The characteristics of the glassbox method:

- Analysis in designing is done completely, it could even go through a testing process.

- Not a design that is done by trial and error, but the design is full of meaning and logic.

- Some of the strategies are very well defined.

In the rational design method, the planner does not always build on their work, it can be built by others. It is different from the design method with the traditional method in that the planner is the actor of the development.

\section{Methods}

\subsection{Research Variable}

In accordance with the theory of the design method according to Jones and Schmitt above, there are 19 variables that are used as parameters in conducting research on the architectural design process for these 8 architects. 19 This variable is a combination of variables obtained from the theory of design methods from Jones and Schmit as shown in the Table 2.1 below.

Table 2.1. Research Variable (Personal Analysis, 2021)

\begin{tabular}{|c|c|c|}
\hline $\begin{array}{l}\text { Design } \\
\text { Methods }\end{array}$ & Kind of Methods & Description \\
\hline \multirow{3}{*}{ Schmitt } & $\begin{array}{l}\text { Routine } \\
\text { Design }\end{array}$ & $\begin{array}{l}\text { - Clarity of design problems } \\
\text { - Using one prototype / identical building } \\
\text { - The results only refine the prototype }\end{array}$ \\
\hline & $\begin{array}{l}\text { Innovative } \\
\text { Design }\end{array}$ & $\begin{array}{l}\text { - } \quad \text { Adapt several identical building prototypes } \\
\text { - The refining results of several prototypes } \\
\text { - The combined result of several prototypes / buildings }\end{array}$ \\
\hline & $\begin{array}{l}\text { Creative } \\
\text { Design }\end{array}$ & $\begin{array}{l}\text { - Case-solving development } \\
\text { - Clarity of function requirements } \\
\text { - The final design influences the original problem }\end{array}$ \\
\hline \multirow{2}{*}{ Jones } & $\begin{array}{l}\text { Traditional } \\
\text { Crafts }\end{array}$ & - Using a drawing system \\
\hline & $\begin{array}{l}\text { Traditional } \\
\text { Drafts }\end{array}$ & - Using a sketch drawing system \\
\hline
\end{tabular}




\begin{tabular}{|c|c|c|}
\hline \multirow{2}{*}{ Jones } & $\begin{array}{c}\text { Modern } \\
\text { Black } \\
\text { Box }\end{array}$ & $\begin{array}{l}\text { - Creative ideas from dreams, inspiration, wangsit } \\
\text { - The concept is difficult to explain, because of the idea of a } \\
\text { - } \text { dream } \\
\text { - The process of coming up with ideas is inexplicable } \\
\text { - The work cannot be criticized } \\
\text { Production capacity depends on the mood of the designer }\end{array}$ \\
\hline & $\begin{array}{l}\text { Modern } \\
\text { Glass } \\
\text { Box }\end{array}$ & $\begin{array}{l}\text { - } \text { Complete design analysis } \\
\text { - } \quad \text { Meaningful and logical design } \\
\text { - The design strategy is well defined }\end{array}$ \\
\hline
\end{tabular}

\subsection{Empirical Data}

From 8 architects who become empirical data source, 4 architects are secondary empirical and the rest are primary empirical. All the architects were quite famous and already had architectural works were selected, where their works had been accepted by the public, both nationally and internationally.

\section{- Architect SE1 (Secondary Empirical 1)}

$\mathrm{He}$ is a national architect who received an academic degree from Australia. In every design he always adheres to that architecture must be able to make a positive contribution to the environment.

An example of his work that adapts to the environment is a building built according to the original soil typology, without any leveling or cut and fill processes.

There are 3 stages of the design carried out by this architect, namely the programming stage, understanding the location and stages of the design process. At the programming stage, the most important thing is to connect groups of activities, understand client wants and goals that manifest into space requirements.

Understanding the location aims to generate architectural form ideas by considering the potential and shortcomings of the site. The design process stage involves combining ideas into a fixed design.

\section{- Architect SE2 (Secondary Empirical 2)}

Is an architect who comes from the city of Semarang. In the design process, he argued that the function of an architect is to characterize the building according to the character of the owner, so it is necessary for an architect to dig deeper and read the owner's personality as a whole. By using the spatial order theory, the occupancy character of the user must receive more attention and is permanent and should not be changed.

The design method used in each design is to use the strength of two elements, namely a cultural approach related to the owner's personality and knowing the strengths of the site.

\section{- Architect SE3 (Secondary Empirical 3)}

Is a famous architect from Japan. He has developed various designs for the urban environment, architecture, furniture, and various other aspects of life.

The design process that he uses is divided into 4 stages. Stage 1 is the formulation of basic elements with an external, environmental, internal approach and other more detailed 
analysis. Stage 2 is the addition of exterior elements based on site plan analysis and other form modifications. Stage 3 is to analyze and modify again and complete the drawing so that it becomes a complete design. And the final stage is to determine the final design and finish all the drawings.

\section{- Architect SE4 (Secondary Empirical 4)}

$\mathrm{He}$ is a Japanese architect who sees architecture as a frame of nature that connects humans with the environment. The fall of the Japanese economy in 1991 prompted him to leave Tokyo and work with local craftsmen. It was there that he had the opportunity to learn about vernacular techniques and natural settings. He has an approach to Contemporary Japanese Architecture that is close to tradition and nature, using light and natural materials to produce transparency. He stated that his architectural works will always be one with the environment.

The stages of his design process can be divided into 5 stages, namely Intense Research, Finding Essence, Integration, Applying Technique and Final Form (Kuma, 2008).

\section{- Architect PE1 (Primary Empirical 1)}

$\mathrm{He}$ is an alumni of YKPN Yogyakarta Architectural Engineering. In carrying out the design process, he divides the 3 stages of the design process, namely the preparation stage which includes extracting site information, local regulations and the environment, and a design approach covering styles, client needs, building functions and budget. The second stage is the pre-design stage with some optional drawing sketches, according to design ideas and suggestions.

The last stage is the final design, including DED (design engineering drawing) and RAB. There are no special habits that are carried out in designing a work. This design process basically applies to all types of architectural works, including government buildings, stateowned enterprises, private companies and interior design.

\section{- Architect PE2 (Primary Empirical 2)}

$\mathrm{He}$ is an Alumni of Diponegoro University. Apart from being a Planning Consultant, he is active in various architectural organizations including the Central Java branch of the Planning Experts Association (IAP), INKINDO Central Java and the Central Java Indonesian Architects Association.

In the design process, he divided the design stages into 3, namely pre-design, design process and implementation process. In the pre-design stage, internal data collection is carried out, including function, style, area, budget, time and purpose of the building, external data, including outside and inside site identification, and supporting data which includes land use, DTK (city planning office) regulations, KKOP (flight operation safety area), and AMDAL (environtmental impact analysis).

At the design process stage, based on the data obtained, processing is carried out from the design idea which is discussed to the owner repeatedly, until the final design is obtained, and then it is entered into the implementation process stage. At this stage, from the results of the DED (detail engineering design), RAB (draft budget) and RKS (work plan dan requirements) drawings, an auction process will be carried out or a direct appointment to the contractor to carry out construction work.

Broadly speaking, the design process stages are the same for all types of work, it's just that for individual small projects the process is shorter, because administrative procedures are simpler than large-scale projects. 


\section{- Architect PE3 (Primary Empirical 3)}

$\mathrm{He}$ is an alumnus architect at Soegijapranoto Catholic University. At this time he is undergoing the architectural profession as a personal architect in Salatiga city, having previously joined a private consultant and contractor company in Semarang.

According to him, the principle of the process or design method in private and government buildings is the same. Basically, the stages of the design process are divided into 3, namely the data collection stage, the design stage and the implementation stage.

The stages of data collection include the client's space requirements, client background and client's basic desires. The design stage includes design sketches, design alternatives, including communication with the client to make the design sketch into the final design. The implementation stage can be carried out by direct appointment or by auction for government projects.

\section{- Architect PE4 (Primary Empirical 4)}

$\mathrm{He}$ is a young architect who graduated from Soegijapranoto University from Semarang. Even though he is relatively young, his work is quite a lot, especially in building houses and offices.

He divided the stages of the architectural design process into 4 stages, namely the interview stage with clients, the location survey stage, the research stage or reference study and the design development stage.

The interview stage with clients is a problem seeking stage, related to client needs, client goals, client budgets and other things that can affect the design. The location survey stages include identification of problems both inside and outside the site, local government regulations, land potential and others. Reference studies are used to find buildings that are identical in function and form to the wishes of the client. The design development stage is the stage of making a product output, in the form of a work drawing and the implementation of the development in accordance with the client's approval.

\section{Discussion}

\subsection{Empirical Data Tabulation}

From the 19 predetermined design process variables and the scoring results on 4 primary empirical data sources and 4 secondary empirical data sources, the scoring results were obtained, where the scoring used a Likert scale, with the highest value being 5 to indicate the maximum level of variable use (perfect), a value of 4 indicates a very good level, a value of 3 indicates a good level, a value of 2 indicates a sufficient level and the lowest value is 1 to indicate the minimum use of design variables or less.

The scoring is determined based on the researcher's interpretation, based on the literature analysis for primary empirical data sources and the results of direct interviews with primary empirical data sources.

\subsection{The Average of Sample Person (Architect)}

By using the SPSS (statistical package for the social science) software with one way ANOVA (analysis of variant) as a statistical analysis system, the mean architects in using the design method variables are shown in the Table 3.1 below. 
Table 3.1. The Average Use's Result of Variables by Sample Person (Personal Analysis, 2021)

Scoring Value Samples to Design Method Variables

\begin{tabular}{|c|c|c|c|c|c|c|}
\hline \multirow{2}{*}{$\begin{array}{l}\text { Sampel } \\
\text { Person }\end{array}$} & \multirow{2}{*}{$\mathrm{N}$} & \multirow{2}{*}{ Mean } & \multirow{2}{*}{$\begin{array}{c}\text { Std. } \\
\text { Deviation }\end{array}$} & \multirow{2}{*}{$\begin{array}{l}\text { Std. } \\
\text { Error }\end{array}$} & \multicolumn{2}{|c|}{$\begin{array}{l}\text { 95\% Confidence Interval for } \\
\text { Mean }\end{array}$} \\
\hline & & & & & Lower Bound & Upper Bound \\
\hline SE 1 & 19 & 2,53 & 1,541 & ,353 & 1,78 & 3,27 \\
\hline SE 2 & 19 & 2,89 & 2,052 & ,471 & 1,91 & 3,88 \\
\hline SE 3 & 19 & 3,42 & 1,61 & ,369 & 2,65 & 4,2 \\
\hline SE 4 & 19 & 3,58 & 1,644 & 377 & 2,79 & 4,37 \\
\hline PE 1 & 19 & 2,63 & 1,571 & ,360 & 1,87 & 3,39 \\
\hline PE 2 & 19 & 3,16 & 1,893 & ,434 & 2,25 & 4,07 \\
\hline PE 3 & 19 & 2,63 & 1,862 & ,427 & 1,73 & 3,53 \\
\hline PE 4 & 19 & 2,89 & 2,052 & ,471 & 1,91 & 3,88 \\
\hline Total & 152 & 2,97 & 1,784 & ,145 & 2,68 & 3,25 \\
\hline
\end{tabular}

Notes

SE : Secondary Empirical (Architect)

PE : Primary Empirical (Architect)

From the Table 3.1 above with sampel persons arranged in order according to empirical data, it can be seen that the average use of variables by the sample is not significantly different. The average use of the design method variable ranges from 2.53 to 3.58 .

While the tabulation of the ranking results or the order of the sample level of user variables can be seen in the Table 3.2 below.

Table 3.2. The Rank of Variable Usage (Personal Analysis, 2021)

Architects' Rank (Average Level) in the Use of Variables

\begin{tabular}{ccc}
\hline Sampel Person & N & alpha $=0,05$ \\
\hline SE 1 & 19 & 2,53 \\
PE 1 & 19 & 2,63 \\
PE 3 & 19 & 2,63 \\
SE 2 & 19 & 2,89 \\
PE 4 & 19 & 2,89 \\
PE 2 & 19 & 3,16 \\
SE 3 & 19 & 3,42 \\
SE 4 & 19 & 3,58 \\
\hline
\end{tabular}

Notes

SE : Secondary Empirical (Architect)

PE : Primary Empirical (Architect) 
From the Table 3.2 above, it turns out that architect SE 4 is the sample that uses the design method variable with the highest average of 3.58. While architect SE 1 is the lowest sample in using the design method variable with a mean value of 2.53 .

\subsection{The Average of Variable}

By using the SPSS software (statistical package for the social science) with one way ANOVA (analysis of variant) as a statistical analysis, the average use of design method variables is obtained as shown in the Table 3.3 below

Table 3.3. Variable Mean Results (Personal Analysis, 2021)

Scoring Value of Each Design Method Variable

\begin{tabular}{|c|c|c|c|c|c|c|c|c|}
\hline \multirow{2}{*}{ Design Method Variables } & \multirow{2}{*}{$\mathrm{N}$} & \multirow{2}{*}{ Mean } & \multirow{2}{*}{$\begin{array}{l}\text { Std. } \\
\text { Deviation }\end{array}$} & \multirow{2}{*}{$\begin{array}{l}\text { Std. } \\
\text { Error }\end{array}$} & \multicolumn{2}{|c|}{$\begin{array}{l}95 \% \text { Confidence } \\
\text { Interval for Mean }\end{array}$} & \multirow[b]{2}{*}{ Min } & \multirow[b]{2}{*}{$\operatorname{Max}$} \\
\hline & & & & & $\begin{array}{l}\text { Lower } \\
\text { Bound }\end{array}$ & $\begin{array}{l}\text { Upper } \\
\text { Bound }\end{array}$ & & \\
\hline - Clarity of design problems & 8 & 4,75 & ,707 & ,250 & 4,16 & 5,34 & 3 & 5 \\
\hline $\begin{array}{l}\text { Using one prototype / identical } \\
\text { building }\end{array}$ & 8 & 1,63 & 1,188 & ,420 & ,63 & 2,62 & 1 & 4 \\
\hline $\begin{array}{l}\text { The results only refine the } \\
\text { prototype }\end{array}$ & 8 & 1,63 & 1,188 & ,420 & ,63 & 2,62 & 1 & 4 \\
\hline $\begin{array}{l}\text { - Adapt several identical building } \\
\text { prototypes }\end{array}$ & 8 & 3,00 & 1,604 &, 567 & 1,66 & 4,34 & 1 & 5 \\
\hline $\begin{array}{l}\text { The refining results of several } \\
\text { prototypes }\end{array}$ & 8 & 1,63 & 1,188 & ,420 & ,63 & 2,62 & 1 & 4 \\
\hline $\begin{array}{l}\text { The combined result of several } \\
\text { prototypes / identical buildings }\end{array}$ & 8 & 1,63 & 1,188 & ,420 &, 63 & 2,62 & 1 & 4 \\
\hline - Case-solving development & 8 & 4,88 & ,354 & ,125 & 4,58 & 5,17 & 4 & 5 \\
\hline $\begin{array}{l}\text { The need for object properties } \\
\text { is not clear }\end{array}$ & 8 & 2,00 & 1,195 & ,423 & 1,00 & 3,00 & 1 & 4 \\
\hline $\begin{array}{l}\text { The final design influences the } \\
\text { original problem }\end{array}$ & 8 & 4,50 & ,756 & ,267 & 3,87 & 5,13 & 3 & 5 \\
\hline - Using a drawing system & 8 & 3,25 & 1,909 & ,675 & 1,65 & 4,85 & 1 & 5 \\
\hline - Using a sketch drawing system & 8 & 4,88 & ,354 &, 125 & 4,58 & 5,17 & 4 & 5 \\
\hline $\begin{array}{l}\text { Creative ideas from dreams, } \\
\text { inspiration, wangsit } \\
\text { The concept is difficult to }\end{array}$ & 8 & 1,00 & 0,0000 & 0,0000 & 1,00 & 1,00 & 1 & 1 \\
\hline $\begin{array}{l}\text { - explain, because of the idea of } \\
\text { a dream }\end{array}$ & 8 & 1,00 & 0,0000 & 0,0000 & 1,00 & 1,00 & 1 & 1 \\
\hline $\begin{array}{l}\text { The process of coming up with } \\
\text { ideas is inexplicable }\end{array}$ & 8 & 1,25 & ,463 & ,164 & ,86 & 1,64 & 1 & 2 \\
\hline - The work cannot be criticized & 8 & 1,13 & ,354 &, 125 & ,83 & 1,42 & 1 & 2 \\
\hline $\begin{array}{l}\text { Production capacity depends on } \\
\text { the mood of the designer }\end{array}$ & 8 & 4,50 &, 535 & 189 & 4,05 & 4,95 & 4 & 5 \\
\hline - Complete design analysis & 8 & 4,50 & ,756 & ,267 & 3,87 & 5,13 & 3 & 5 \\
\hline - Meaningful and logical design & 8 & 4,88 & ,354 & ,125 & 4,58 & 5,17 & 4 & 5 \\
\hline $\begin{array}{l}\text { The design strategy is well } \\
\text { defined }\end{array}$ & 8 & 4,38 & ,916 & ,324 & 3,61 & 5,14 & 3 & 5 \\
\hline TOTAL & 152 & 2,97 & 1,784 & , 145 & 2,68 & 3,25 & 1 & 5 \\
\hline
\end{tabular}


From the table above, it can be seen that there are several variables in the design process or method that get the same value for all sample persons. with a standard deviation of 0 , with the lowest mean value ( 1 - less used by architects), that's the variable idea of creativity comes from dreams, inspiration or wangsit and concept variables that are difficult to explain because ideas come from dreams, inspiration or wangsit. Where, according to Jones, the two variables are an extension of the black box method. This means that the sample person is less able to use this method.

The rank of design process variables from lowest to highest order can be seen in the table 3.4 below. Where the highest average is 4.88 , indicating that in carrying out the design process, the sample person first explores the clarity of the needs for building functions to be designed for the owner, the use of image facilities in visualizing the results of the design and the results of the built design have certain and logical meanings

Table 3.4. The Rank of Variable Usage (Personal Analysis, 2021)

Ranking (Average Levels) of Variables Used by Architects

\begin{tabular}{llc}
\multicolumn{1}{c}{ Variable Items } & Subset for \\
& & $\begin{array}{c}\text { Alpha } \\
=0,05\end{array}$ \\
\hline - Creative ideas from dreams, inspiration, wangsit & 8 & 1,00 \\
- The concept is difficult to explain, because of the idea of a dream & 8 & 1,00 \\
- The work cannot be criticized & 8 & 1,13 \\
- The process of coming up with ideas is inexplicable & 8 & 1,25 \\
- Using one identical prototype & 8 & 1,63 \\
- The results only refine one prototype & 8 & 1,63 \\
- The refining results of several prototypes & 8 & 1,63 \\
- The combined result of several identical prototypes & 8 & 1,63 \\
- The need for object properties is not clear & 8 & 2,00 \\
- Adapt several identical building prototypes & 8 & 3,00 \\
- Using Shape Exploratory Studies & 8 & 3,25 \\
- The design strategy is well defined & 8 & 4,38 \\
- The final design influences the original problem & 8 & 4,50 \\
- Production capacity depends on the mood of the designer & 8 & 4,50 \\
- Complete design analysis & 8 & 4,50 \\
- Clarity of design problems & 8 & 4,75 \\
- Clarity of function requirements & 8 & 4,88 \\
- Using a sketch drawing system & 8 & 4,88 \\
\hline
\end{tabular}

\section{Conclusion}

From the above research it can be concluded that:

- The tendency of architects to use the glass box design method from Jones' theory and creative design from Schmitt. 
- The order of magnitude of the average use of the design process variables does not affect the final design result and does not indicate whether the architect's work is good or not.

- There is no design process found from empirical data sources, which deviates from the theory of design methods or design processes which are contrary to the theory of design methods.

- In general, an architect has different stages of the design process according to the character and experience of each architect. However, all the choices of the design process are in accordance with the design method theory, both the design method proposed by Schmitt and the Jones design method. The only difference lies in the order of the design process, simplification or detailing of the stages of the theory, or precisely the combination of the two theories.

\section{References}

Aditjipto, M. (1999). Jenis Masalah Perancangan dan Jenis Pendekatannya. Jurnal Dimensi Teknik Arsitektur Petra, 27(2). https://doi.org/https://doi.org/10.9744/dimensi.27.2.

Afify, H. M. N., Alhefnawi, M. A. M., Istanbouli, M. J., Alsayed, A. H., \& Elmoghazy, Z. A. A. E. (2021). An evaluation of physical model-making as a teaching method in the architectural design studio - A case study at Imam Abdulrahman Bin Faisal University. Ain Shams Engineering Journal, 12(1), 1123-1132. https://doi.org/https://doi.org/10.1016/j.asej.2020.07.002

Asimow, M. (1962). Introduction to Design. Los Angeles: NJ: Prentice-Hall.

Billings, K., \& Akkach, S. (1992). A study of ideologies and methods in contemporary architectural design teaching: part 1: ideology. Design Studies, 13(4), 431-450. https://doi.org/https://doi.org/10.1016/0142-694X(92)90171-6

Bognar, B. (2005). Kengo Kuma Selected Work. New York: Princeton Architectural Press.

Carrasco, M. D. O., \& Chen, P.-H. (2021). Application of mixed reality for improving architectural design comprehension effectiveness. Automation in Construction, 126. https://doi.org/https://doi.org/10.1016/j.autcon.2021.103677

Geest, M. van, Tekinerdogan, B., \& Catal, C. (2021). Design of a reference architecture for developing smart warehouses in industry 4.0. Computers in Industry, 124. https://doi.org/https://doi.org/10.1016/j.compind.2020.103343

Heath, T. (1984). Method in Architecture. Norwich: John Wiley \& Sons.

Heil, N. C., \& Vitalis, L. (2020). Biology and architecture: An ongoing hybridization of scientific knowledge and design practice by six architectural offices in France. Frontiers of Architectural Research. https://doi.org/https://doi.org/10.1016/j.foar.2020.10.002

Ibrahim, A. F., Attia, A. S., Bataineh, A. M., \& Ali, H. H. (2020). Evaluation of the online teaching of architectural design and basic design courses case study: College of Architecture at JUST, Jordan. Ain Shams Engineering Journal. https://doi.org/https://doi.org/10.1016/j.asej.2020.10.006

Jiao, Z., Yu, B., Wu, S., Shang, Y., Huang, H., Tang, Z., ... Li, C. (2019). An intelligent design method for actuation system architecture optimization for more electrical aircraft. Aerospace Science and Technology, 93. https://doi.org/https://doi.org/10.1016/j.ast.2019.03.048

Jones, C. (1972). Design Methods, Seeds of Human Futures. London: Willey Interscience.

Kuma, K. (2008). Architecture Words 2: Anti-Object. London: Architectural Association.

Pawitro, U. (2009). Pemahaman Keterkaitan "Teori Arsitektur" - Kegiatan "Perancangan" dan "Kritik Karya" dalam Arsitektur. Jurnal Itenas Rekayasa, 13(4).

Louati, H., Bechikh, S., Louati, A., Hung, C.-C., \& Said, L. B. (2021). Deep convolutional neural network architecture design as a bi-level optimization problem. Neurocomputing, 439, 44-62. https://doi.org/https://doi.org/10.1016/j.neucom.2021.01.094 
Luck, R. (2019). Design research, architectural research, architectural design research: An argument on disciplinarity and identity. Design Studies, 65, 152-166. https://doi.org/https://doi.org/10.1016/j.destud.2019.11.001

Pearson, L. C. (2020). A machine for playing in: Exploring the videogame as a medium for architectural design. Design Studies, 66, 114-143. https://doi.org/https://doi.org/10.1016/j.destud.2019.11.005

Pena, M. L. C., Carballal, A., Fernandez, N. R., Santos, I., \& Romero, J. (2021). Artificial intelligence applied to conceptual design. A review of its use in architecture. Automation in Construction, 124. https://doi.org/https://doi.org/10.1016/j.autcon.2021.103550

Ratodi, M. (2017). Metode Perancangan Arsitektur Edisi 1. Nulisbuku.com.

Schmitt, G., \& Chen, C. (1991). Classes of Design - Classes of Methods - Classes of Tools. Design Studies, 12(4), 246-251.

Seinajoki, \& Jyvaskyla. (2012). The Idea of the Primary Stage in Alvar Aalto's Drawings Through the Analysis of the Design Process of "Vuoksenniska Church (1955-1958).

Stals, A., Jancart, S., \& Elsen, C. (2021). Parametric modeling tools in small architectural offices: Towards an adapted design process model. Design Studies, 72. https://doi.org/https://doi.org/10.1016/j.destud.2020.100978

Zou, Y., Zhan, Q., \& Xiang, K. (2021). A comprehensive method for optimizing the design of a regular architectural space to improve building performance. Energy Reports, 7, 981996. https://doi.org/https://doi.org/10.1016/j.egyr.2021.01.097 